\title{
Natural and Induced (Eyestalk Ablation) Molt Cycle in Freshwater Rice Field Crab Oziothelphusa Senex Senex
}

\author{
Neelima Hosamani ${ }^{1}$, Ramachandra Reddy Pamuru** and Sreenivasula Reddy Pamanji ${ }^{2}$ \\ ${ }^{1}$ Department of Biochemistry, Yogi Vemana University, Kadapa, Andhra Pradesh, India \\ ${ }^{2}$ Department of Zoology, Sri Venkateswara University, Tirupati, Andhra Pradesh, India
}

\begin{abstract}
In crustaceans, molting is the process of shedding old exoskeleton and is required for the somatic growth of new exoskeleton for its growth. The molting processes in crustaceans vary from one species to other and also vary with the environmental conditions. In the present study the molt cycle of freshwater crab Oziothelphusa senex senex was studied. The size of crabs selected for the study is $30 \pm 2 \mathrm{~g}$. The natural molt cycle is consisting of intermolt (C1, C2, C3 and C4), premolt (D1, D2, D3 and D4), ecdysis (E) and post molt (A1, A2, B1 and B2) stages were measured and the percentage of each stage in the molt cycle was calculated. The biggest stage in the $O$. senex senex molt cycle is intermolt stage $(90.0 \%)$ and shortest one is ecdysis $(0.01 \%)$. Induced molt cycle was studied by eyestalk extirpation (ESX) and observed that $60.71 \%$ of male crabs and $52.0 \%$ female crabs were molted after 28 th day of extirpation suggesting the role of eyestalk principle in regulating the molting process.
\end{abstract}

Keywords: Molt cycle; Eyestalk ablation; Maxillipede; Setae; Oziothelphusa senex senex

\section{Introduction}

Arthropods, encased in protective cuticles have solved the problem of size increase by a discontinuous growth pattern, the molting cycle. Molting is one of the most important physiological processes occurring during the arthropod life cycle and is controlled by moltinhibiting hormone (MIH) and molting hormone, ecdysone [1-3]. In crustaceans, the growth cycle consists of a series of molts following intermolt periods. The growth in a typical decapod crustacean is a step wise process happening during the molt, while the resources for growth are gathered during intermolt period [4]. The growth, weight gain takes place during the molt itself, when the animal takes water into the body and thus increases in size, weight and volume. In crabs, the weight gain at molt is normally between twenty and thirty percent of premolt stage weight. During intermolt the animal substitutes its water content with tissue growth, and the weight gain during the long intermolt is normally less than $5 \%$ of immediate postmolt weight. Also, the water content of hemolymph decreases during the intermolt [5].

In crustaceans, the conventional method for inducing growth is eyestalk ablation (ESX) that involves the removal of molt inhibiting hormone (MIH) and release of molting hormone the ecdysone. In which MIH is produced in the eyestalk and molting hormone is produced in Y-organ. By eyestalk ablation MIH action is excluded or suppressed simultaneously it allows molting hormone to act. Thus on removal of eyestalk causes increase of ecdysteroid secretion from Y-organ which includes precocious molting in many decapods species [6-9]. On removal of eyestalk, mortality increases because it removes four ganglia from each eyestalk, a considerable portion of central nervous system thereby induces hormonal imbalance and stress [10]. Besides this decreased hemolymph osmolarity by ESX has been reported in crustaceans [11,12] Along with growth unilateral ESX also shortens molt interval and stimulate gonad maturation is evidenced in several crustaceans like Metapenaeus dobsoni [12] Astacus leptodactylus [13] scylla serrata [8].

The criteria used in the present study to characterize the molt cycle stages in the crab O. senex senex is essentially similar to the stage description developed by Drach $[14,15]$ and other workers (see the review of) Kurup [16] and redescribed by Reddy [17]. Though, the change in behavior and morphology at the stages of the molt cycle of O. senex senex broadly similar to those of other decapod crustaceans, the duration of the various stages and the characteristics used in their recognition vary widely. However no clear demarcation of the molt stages of natural molt cycle has been noted in the crab O. senex senex and hence the present study is aimed to focus on the measurement of each and every sub-stage of natural molt cycle along with role of eyestalk on molting in crab Oziothelphusa senex senex.

\section{Materials and Methods}

\section{Animals}

The freshwater rice field crab, O. senex senex $(30 \pm 2 \mathrm{~g})$ were used as experimental animal for the present investigation. The crabs (both male and female) were collected from rice field and irrigation canals (free from pesticides and pollutants) in and around Renigunta $\left(13.6^{\circ} \mathrm{N}\right.$ and $79.5^{\circ} \mathrm{E}$ ) Andhra Pradesh (South India). The crabs were brought to the laboratory and maintained in the laboratory at $28 \pm 1^{\circ} \mathrm{C}$ in tubs partially filled with aged fresh water. They were acclimatized to laboratory conditions (12:12 L:D) for at least 7 days before being used in experiments. The water in the tubs was changed daily. During the experiment, the crabs were fed on sheep meat ad libitum. Feeding was stopped one day before the commencement of experiment to avoid any internal complications.

\section{Determination of natural molt cycle}

A total of 350 animals (200 males and 150 females) were used to

*Corresponding author: Ramachandra Reddy Pamuru, Department of Biochemistry, Yogi Vemana University, Kadapa-516003, Andhra Pradesh, India, Tel: +91-8562-225425; Fax: +91-8562-225419; E-mail: reddyprbiotech@gmail.com

Received February 14, 2016; Accepted April 25, 2016; Published April 27, 2016

Citation: Hosamani N, Pamuru RR, Pamanji SR (2016) Natural and Induced (Eyestalk Ablation) Molt Cycle in Freshwater Rice Field Crab Oziothelphusa Senex Senex. J Aquac Res Development. 7: 424. doi:10.4172/2155-9546.1000424

Copyright: @ 2016 Hosamani N, et al. This is an open-access article distributed under the terms of the Creative Commons Attribution License, which permits unrestricted use, distribution, and reproduction in any medium, provided the original author and source are credited. 
study the natural molt cycle in this study. The natural molt cycle stages in the freshwater crab Oziothelphusa senex senex were determined according to the method described by Drach [14,15], modified by Reddy [17]. The molt cycle in the crab O. senex senex consists of four molt periods viz., postmolt, intermolt, premolt and ecdysis. The postmolt period (divided into two stages $\mathrm{A}$ and $\mathrm{B}$ ) is sub-divided into four stages, viz., $A_{1}, A_{2}, B_{1}$ and $B_{2}$; the intermolt into $C_{1}, C_{2}, C_{3}$ and $C_{4}$ and the premolt into $\mathrm{D}_{0}, \mathrm{D}_{1}, \mathrm{D}_{2}, \mathrm{D}_{3}$ and $\mathrm{D}_{4}$. The duration of total molt cycle of the crab O. senex senex observed by setal development in the mastigobranch of third maxillipede and the characteristic features of molt cycle were summarized. The experiments were conducted twice during the months of June and July in 2014 and 2015.

\section{Role of Eyestalk ablation on molting}

In the present study, in order to determine the role of eyestalks in the regulation of molting in the crab O. senex senex, bilateral eyestalk ablation experiments were conducted in both males and females. The major purpose of eyestalk ablation is to induce molting activity in the crab under laboratory conditions.

Experiments for male and female crabs were conducted individually. A total of 130 male and 130 female crabs with body weight of $28 \pm 2 \mathrm{~g}$ were divided into three groups for each gender. For each experiment animals were divided into three groups. Group I served as controls with 10 animals and sacrificed on day ' 0 ' of experiment and recorded the molt stage. Group II served as concurrent control and were maintained along with experimental animals. Group III served as ESX and maintained up to 28 days. Selected number (Tables 1 and 2) of group II and III animals were sacrificed on $7^{\text {th }}, 14^{\text {th }}, 21^{\text {st }}$ and $28^{\text {th }}$ day of experiment to determine the molt stages. The molt stages were determined by observing the setal development in the mastigobranch of third maxillepede.

\section{Results and Discussion}

\section{Measurement of postmolt stage}

The postmolt stage starts immediately after molt and it occupies $5.3 \%$ of total molt cycle duration. The characteristic feature of postmolt is that of hardening and calcification of the carapace. Postmolt was divided into stages $A$ and $B$, and are sub-divided into $A_{1}, A_{2}, B_{1}$ and $B_{2}$ respectively.

Stage A: The duration of stage A is $2.7 \%$ of total molt cycle duration and $50.94 \%$ (Figure 1) of postmolt duration. Stage A begins immediately after a crab has cast the exuvium. The stage is dominated by absorption of water, when a crab expands its volume up to $50 \%$. Due to water absorption, the weight of the body is fluctuating.

In sub-stage $A_{1}$ the animal is extremely quiescent and the exoskeleton was as soft as, parachment and shiny. The body appears dark brown or black in colour. The size of the body increased in freshly molted animal due to rapid water absorption and the animal appears blotted. At this sub-stage, the legs of the animal are not functional and the crab cannot lift its body on its legs or support its weight. The crab does not feed at this sub-stage and it occupies $0.9 \%$ of total molt cycle duration (Table 3) and $16.98 \%$ of postmolt duration (Figure 1).

In sub-stage $A_{2}$, the crab is still inactive and is unable to lift its body on its legs, but moves with difficulty. At the end of this sub-stage the expansion of exoskeleton is completed and its colour becomes shiny black. The sub-stage $\mathrm{A}_{2}$ occupies $1.8 \%$ of total molt cycle duration (Table 1 ) and $33.86 \%$ of postmolt duration (Figure 1). The animal is inactive and non-feeding at this stage.

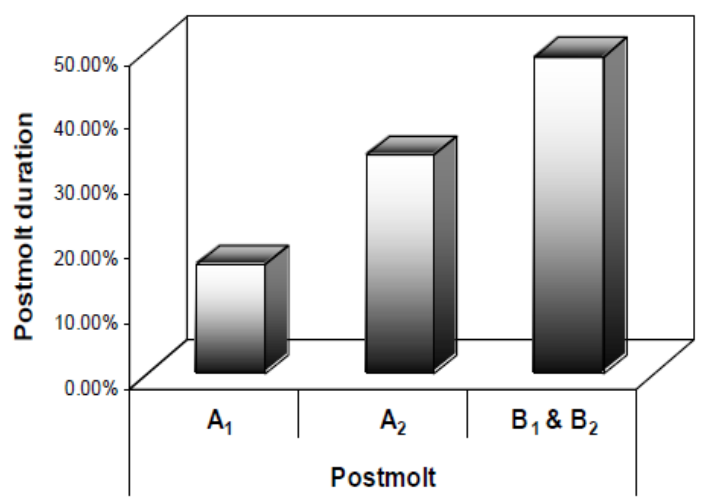

Figure 1: The duration of different sub-stages of post molt in the crab Oziothelphusa senex senex.

\begin{tabular}{|l|l|l|l|l|l|l|l|}
\hline Group & \multicolumn{7}{|c|}{ Days after eyestalk ablation } \\
\cline { 2 - 7 } & Day '0' & $\mathbf{1}$ & $\mathbf{7}$ & $\mathbf{1 4}$ & $\mathbf{2 1}$ & $\mathbf{2 8}$ \\
\hline Control $(\mathrm{n}=10)$ & $\mathrm{C}_{4}(10.0)$ & - & - & - & - & - \\
\hline $\begin{array}{l}\text { Concurrent } \\
\text { control }(\mathrm{n}=20)\end{array}$ & - & $\mathrm{C}_{4}(4.0)$ & $\mathrm{C}_{4}(4.0)$ & $\mathrm{C}_{4}(4.0)$ & $\mathrm{C}_{4}(4.0)$ & $\mathrm{C}_{4}(4.0)$ \\
\hline $\begin{array}{l}\text { Eyestalk } \\
\text { Ablated }(\mathrm{n}=100)\end{array}$ & - & $\mathrm{C}_{4}(8.0)$ & $\mathrm{C}_{4}(6.0)$ & $\mathrm{D}_{1}(10.0)$ & $\mathrm{D}_{1}(3.0)$ & $\mathrm{D}_{2}(2.0)$ \\
\hline & & & $\mathrm{D}_{1}(2.0)$ & $\mathrm{D}_{2}(4.0)$ & $\mathrm{D}_{3}(4.0)$ & $\mathrm{D}_{4}(4.0)$ \\
\hline & & & & $\mathrm{D}_{3}(4.0)$ & $\mathrm{D}_{4}(5.0)$ & $\mathrm{D}_{4}(5.0)$ \\
\hline & & & & & Molted (10.0) & Molted (17.0) \\
\hline
\end{tabular}

Values in parentheses are number of animals.

16 crabs died after eyestalk ablation during experimentation.

Table 1: Different molt stages of the male crab on different days after eyestalk ablation.

Stage B: In stage B, the hardening of exoskeleton takes place. Feeding does not yet begin. Stage B occupies $2.6 \%$ of total molt cycle duration (Table 1) and $49.16 \%$ of postmolt duration (Figure 1). In the sub-stage $B_{1}$, the prothoracic area becomes hard and the other areas of carapace (mesogastric, urogastric, cardiac, anterior and posterior bronchial regions) become firm but easily depressible. Propodus and merus of chelate leg are hard but can be bent without cracking. At the end of the sub-stage $B_{1}$ crab starts feeding. In sub-stage $B_{2}$, only mesogastric and urogastric areas attain rigidity but the anterior and posterior branchial regions are in firm state. In this sub-stage, carpus and propodus are assum uniform hardness.

\section{Measurment of intermolt or stage C}

Intermolt or stage $\mathrm{C}$ is the longest period (occupying 90.0\%) of the total molt cycle (Table 1), in which the animal leads a normal life. The water content of the crab is gradually replaced by tissue. During this stage the exoskeleton is mineralized and it assumes the typical rigid form. The sub-stage $\mathrm{C}_{1}$ occupies $3.6 \%$ of total molt cycle duration (Table 1) and $4.0 \%$ of intermolt duration (Figure 2). Except cardiac area of carapace, the remaining regions are hardened and the body has achieved its definite colouration. In sub-stage $\mathrm{C}_{2}$ the entire carapace regions are hard. The appendages of crab are also uniformly hard and the animal feeds actively in this sub-stage. The sub-stage $\mathrm{C}_{2}$ occupies $6.4 \%$ of total molt cycle duration (Table 1) and $7.11 \%$ of intermolt duration (Figure 2).

In sub-stages $\mathrm{C}_{3}$ and $\mathrm{C}_{4}$ the animals show normal locomotor and prandial activity. These two sub-stages cannot be strictly demarcated in 
the present crab. The duration of these sub-stages lasts few months and is depends on internal and external conditions. In case of laboratory maintained animals, the duration of these sub-stages is more than the natural ones. However, in the total molt cycle, the duration of these sub-stages occupy nearly $80.00 \%$ (Table 1 ) and $88.89 \%$ of intermolt duration (Figure 2). In these stages, the crabs show normal locomotor and feeding activity.

\section{Measurment of premolt or stage $D$}

Stage D is the premolt period of molt cycle and it occupies $4.69 \%$ of molt cycle duration (Table 1). During this stage, the crab prepares for the molt by accumulating reserves, reabsorbing the calcium from the shell and synthesizing the new layer of new cuticle. The crab ceases feeding at some point of time during this stage. The characteristic feature of premolt is formation of new setae in the mastigobranch of third maxillepede. This phenomenon was first observed by Braun [18] and is of great importance in determining the incipience of molting. In Oziothelphusa senex senex, the mastigobranch of third maxillepede at intermolt (sub-stage $\mathrm{C}_{4}$ ) contain numerous hair-like setae (Figure 3).

In the sub-stage $\mathrm{D}_{0}$, the underlying epidermis was separated from the exoskeleton and it is termed as apolysis. In sub-stage $\mathrm{D}_{1}$ the retraction of epidermal layer from old cuticle and loss of external setae was observed with appearance of rudiments of setal grooves from the old epidermal layer in mastigobranch for development of new setae (Figure 4$)$. These sub-stages $\left(D_{0}\right.$ and $D_{1}$ ) occupy $0.3 \%$ of the total molt cycle duration (Table 1) and $6.39 \%$ of premolt duration (Figure 5).

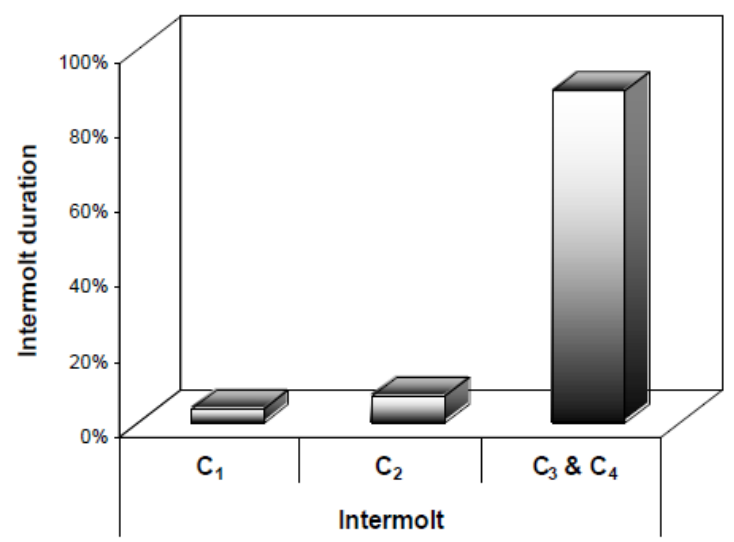

Figure 2: The duration of different sub-stages of intermolt in the crab Oziothelphusa senex senex.

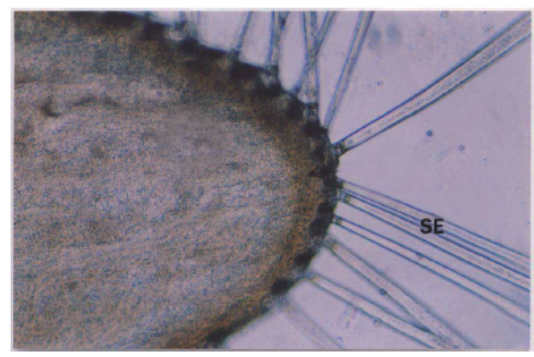

Figure 3: The intermolt (stage C4) mastigobranch of third maxillepede of Oziothelphusa senex senex showing external setae (SE) $100 \mathrm{X}$.

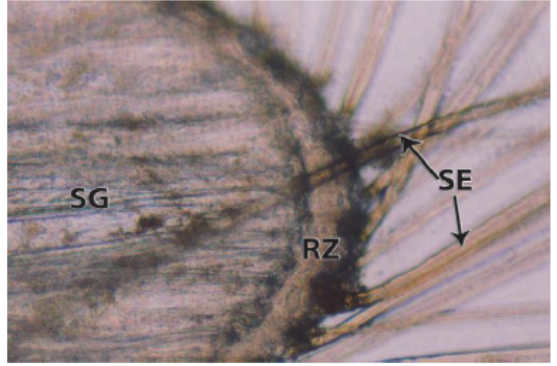

Figure 4: The mastigobranch of third maxillepede of premolt (sub-stage D2) crab showing newly formed setal grooves (SG) with retraction zone with external setae (SE). $100 \mathrm{X}$.

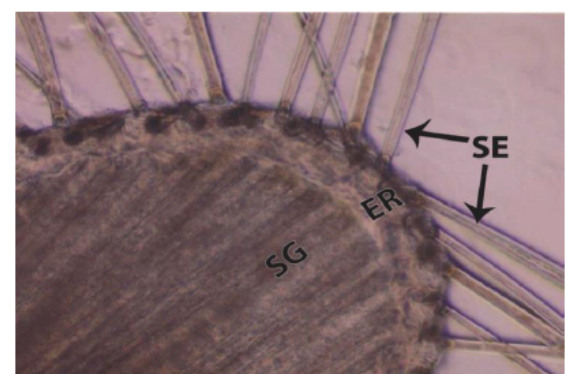

Figure 5: The mastigobranch of third maxillepede of premolt (sub-stage D1) crab showing retraction of epidermal layer.

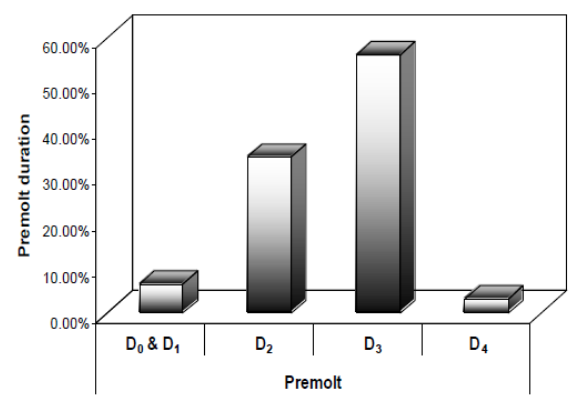

Figure 6: The duration of different sub stages of premolt in the crab Oziothelphusa senex senex.

The sub-stage $\mathrm{D}_{2}$ occupies $1.6 \%$ of the total molt cycle duration (Table 1) and $34.08 \%$ of premolt duration (Figure 6). In this substage, the new pigment layer is synthesized. This layer is underneath of old exoskeleton and can be observed only by removing a part of old exoskeleton. The newly formed setal grooves in the mastigobranch are clearly visible and easily defined (Figure 4 ).

In sub-stage $\mathrm{D}_{3}$ the crab ceases feeding and locomotion. The newly formed integument has become completely detached from the old exoskeleton. A remarkable colour differentiation was observed between old exoskeleton and newly formed integument. The setal articulation and the newly formed setae are clearly visible and discretely arranged within the setal grooves. The retraction zone formed in between the epidermal layer and cuticle was more and clearly demarcated (Figure 7). In this sub-stage, due to the re-absorption of calcium from old exoskeleton, the hemolymph of the crab is milky. The sub-stage $\mathrm{D}_{3}$ 
occupies $2.64 \%$ of the total molt cycle duration (Table 1 ) and $56.34 \%$ of premolt duration (Figure 6).

The sub-stage $\mathrm{D}_{4}$ occupies only $0.15 \%$ of the total molt cycle duration (Table 1) and $3.19 \%$ of premolt duration (Figure 6). In sub-stage $\mathrm{D}_{4}$, the line of dehiscence is well marked and is characterized by the opening of the line. The inner newly formed integument is dark brown or black in colour and remains detached from old exoskeleton. The carapace becomes very thin and papery in texture and breaks easily under slight pressure. At this sub-stage due to the movement of new setae to the peripheral region of mastigobranch, the disappearance of epidermal retraction zone was observed in the base of the mastigobranch (Figures $8 \mathrm{a}$ and $8 \mathrm{~b}$ ). The hemolymph of the animal is milky and the crabs are inactive and cease feeding.

\section{Measurment of Ecdysis or Stage E}

Stage E, or ecdysis is shortest period in the molt cycle and it occupies only $0.01 \%$ of the total molt cycle duration (Table 1). Ecdysis is the shedding of exoskeleton and not considered as a part of classical molt stages. All the changes observed in the premolt period lead to shedding of the old exoskeleton. During stage E nearly all the activities of the crab ceased. Active withdrawal of the old exoskeleton lasted slightly more than 15 minutes in five instances observed in full; but if withdrawal prolonged abnormally, it usually ends in death. All the appendages like legs and mouth parts are withdrawn from the old exoskeleton during exuviation. During exuviation the crab is completely helpless. All the crabs are molted late at night except one. When ecdysis is completed, the animal becomes quiescent again, but pumps water through its mouth at the maximal rate. The exoskeleton of freshly molted crab becomes soft and is stretched due to absorption of water. The size of the animal after ecdysis found to be much larger than the old one.

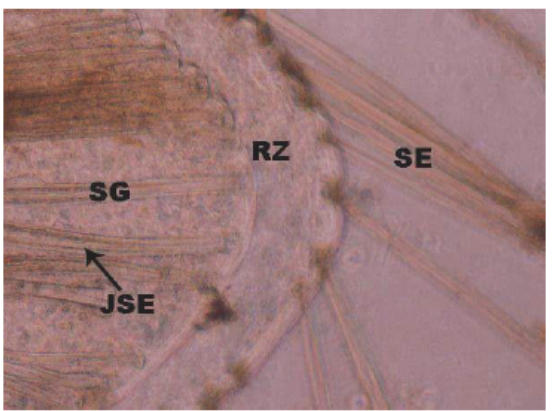

Figure 7: The mastigobranch of third maxillepede (sub-stage D3) of the crab Oziothelphusa senex senex showing setal articulation (SA), newly formed juvenile setae (JSE) in the setal grooves (SG) and clear retraction zone (RZ) in between epidermal layer and cuticle. SE = external setae; 100X.

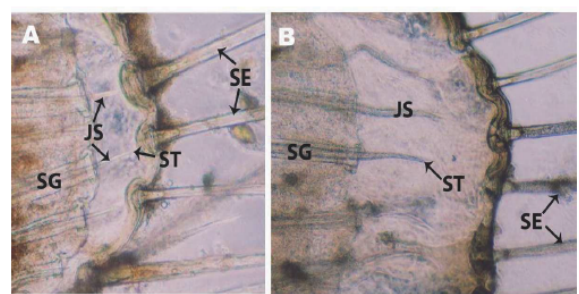

Figure 8: The mastigobranch of third maxillepede showing early sub-stage D4 (A) and late sub-stage D4 (B) crab showing the extruviation of juvenile setae (JS) from the setal grooves (SG) with distinct setal tips (ST). SE = external setae; $100 X$.

\section{Role of eyestalks on molting}

The experimental animals were observed to determine the molt stages on first, seventh, fourteenth, twenty first and twenty eighth day after eyestalk ablation. The molt stages were determined by observing the setal development in the mastigobranch of third maxillepede. The incipience of premolt stage was observed 7 days after eyestalk ablation in males, but the percentage of males entered into the premolt is less (25.0) (Table 2). In females, the premolt substages $D_{1}$ and $D_{2}$ were observed 14 days post eyestalk extirpation (Table 3), indicating the molt initiation was started after the day 7 and before day 14 after eyestalk ablation. The males exhibited $\mathrm{D}_{1}, \mathrm{D}_{2}$ and $\mathrm{D}_{3}$ sub-stages of premolt on the $14^{\text {th }}$ day of experiment (Table 2). On the 21st day after eyestalk ablation some of the males and females exhibited advanced premolt stages (stage $\mathrm{D}_{3}$ and $\mathrm{D}_{4}$ ) and some are molted (Tables 2 and 3 ). The percentage of males and females entered into different substages of premolt and molted on the $21^{\text {st }}$ day after eyestalk ablation was presented in Figure 9. On this day of experiment percentage of molted females (34.78) is lesser than the molted males (45.45). Most of the eyestalk ablated males and females exhibited advanced premolt sub-stages (stage $\mathrm{D}_{3}$ and $\mathrm{D}_{4}$ ) and several crabs molted on the $28^{\text {th }}$ day of experiment. Figure 10 shows the percentage of eyestalk ablated males and females entered in to the different sub-stages of premolt and molted on $28^{\text {th }}$ day after eyestalk ablation. On this day of experiment, the percentage of males (60.71) molted is higher than the females (52.0). None of the crabs in concurrent control groups (both the sexes) entered into premolt even after 28 days (Tables 2 and 3), indicating that no other factor involved during the experimentation on molting. The percentage of mortality during experimental period in an eyestalk ablated males and females were 16.0 and 20.0 respectively.

\begin{tabular}{|l|l|l|l|l|l|l|}
\hline \multirow{2}{*}{ Group } & \multicolumn{7}{|l|}{ Days after eyestalk ablation } \\
\cline { 2 - 7 } & Day '0' & $\mathbf{1}$ & $\mathbf{7}$ & $\mathbf{1 4}$ & $\mathbf{2 1}$ & $\mathbf{2 8}$ \\
\hline Control $(\mathrm{n}=10)$ & C4 (10.0) & - & - & - & - & - \\
\hline $\begin{array}{l}\text { Concurrent } \\
\text { control }(\mathrm{n}=20)\end{array}$ & - & C4 (4.0) & C4 (4.0) & C4 (4.0) & C4 (4.0) & C4 (4.0) \\
\hline $\begin{array}{l}\text { Eyestalk } \\
\text { Ablated }(n=100)\end{array}$ & - & C4 (8.0) & C4 (8.0) & D1 (10.0) & D1 (5.0) & D2 (3.0) \\
\hline & & & & D2 (6.0) & D3 (4.0) & D4 (4.0) \\
\hline & & & & & D4 (5.0) & D4 (4.0) \\
\hline
\end{tabular}

Table 2: Different molt stages of the female crab on different days after eyestalk ablation.

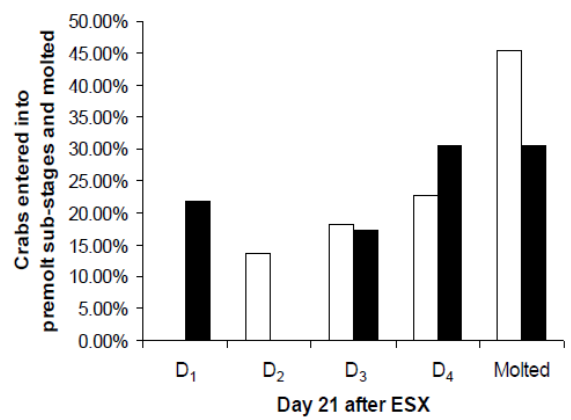

Figure 9: The cumulative percentage of crabs (male and female) entered into premolt and molted on $21^{\text {st }}$ day after eyestalk ablation (ESX). Open bars Males; solid to bars - females. 


\begin{tabular}{|c|c|c|c|c|c|c|c|}
\hline Molt stage & Sub- stage & Feeding & Activity & Exoskeleton & Epidermis & Diagnostic characters & $\%$ of total molt cycle \\
\hline Post molt & & & & & & & 5.3 \\
\hline \multirow[t]{2}{*}{ A } & A1 & None & Weak & Soft and shiny & Transparent & $\begin{array}{l}\text { Epidermis closely applied to new cuticle tip; } \\
\text { internal tissues disorganized. }\end{array}$ & \\
\hline & A2 & None & Weak & Soft & Granular & $\begin{array}{l}\text { Epidermis closely applied to new cuticle tip; } \\
\text { internal tissues disorganized. }\end{array}$ & 2.7 \\
\hline \multirow[t]{2}{*}{ B } & B1 & None & Restored & Hardening & Granular & $\begin{array}{c}\text { Chromatophores visible and internal tissues } \\
\text { appear }\end{array}$ & 2.6 \\
\hline & B2 & Minimal & Minimal & Hardening & Granular & Appearance of more chromatophores. & \\
\hline Intermolt & & & & & & & 90 \\
\hline \multirow[t]{4}{*}{$\mathrm{C}$} & C1 & Minimal & Maximal & Hard & Granular & $\begin{array}{l}\text { Internal cone formation begins; setal organs } \\
\text { become visible. }\end{array}$ & 3.6 \\
\hline & $\mathrm{C} 2$ & Maximal & Maximal & Hard & Granular & Completion of internal cone formation. & 6.4 \\
\hline & C3 & Maximal & Maximal & Hard & Granular dense & Granular matrix retraction completed. & 80 \\
\hline & C4 & Maximal & Maximal & Hard & $\begin{array}{l}\text { Granular and very } \\
\text { dense }\end{array}$ & $\begin{array}{l}\text { The setal lumen was pinched off at the base } \\
\text { of the setae near the setal articulation. }\end{array}$ & \\
\hline Premolt & & & & & & & 4.69 \\
\hline \multirow[t]{5}{*}{ D } & D0 & Maximal & Maximal & No new cuticle yet & Apolysis (retraction) & No setal development was observed. & 0.3 \\
\hline & D1 & Minimal & Maximal & $\begin{array}{l}\text { Appearance of new } \\
\text { pigmented layer. }\end{array}$ & Invaginates & Initiation of setal articuloation. & \\
\hline & $\mathrm{D} 2$ & Minimal & Maximal & $\begin{array}{l}\text { Gap formation } \\
\text { between old and } \\
\text { new cuticle }\end{array}$ & Invaginates & Increase of setal articulation. & 1.6 \\
\hline & D3 & Stopped & Weak & $\begin{array}{l}\text { Thinning of old } \\
\text { cuticle }\end{array}$ & Invagenates & $\begin{array}{l}\text { Development of new setae and milky } \\
\text { hemolymph. }\end{array}$ & 2.64 \\
\hline & D4 & None & Ceased & $\begin{array}{l}\text { Paper-like old } \\
\text { cuticle }\end{array}$ & $\begin{array}{l}\text { Completion of } \\
\text { invagintion }\end{array}$ & $\begin{array}{l}\text { Withdrawal of old setae \& formation of new } \\
\text { setae. }\end{array}$ & 0.15 \\
\hline Ecdysis & $\mathrm{E}$ & None & Ceased & Old cuticle is shed & Transparent & Soft body & 0.01 \\
\hline
\end{tabular}

Table 3: The characteristic features of molt cycle in the fresh water rice field crab Oziothelphusa senex senex.

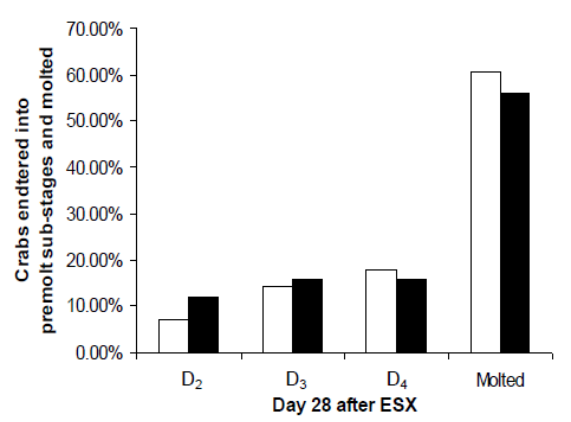

Figure 10: The cumulative percentage of crabs (male and female) entered into premolt and molted on $28^{\text {th }}$ day after eyestalk ablation (ESX). Open bars - males; Solid bars - females.

The role of eyestalks in the regulation of molting was studied in several crustaceans see reviews [19-21] have also observed the shortened molt cycles in the eyestalk ablated male and female prawns Macrobrachium rosenebergii. Precocious molting has been well documented in spider crab Libinia emarginata [22] and freshwater prawn Macrobrachium rosenbergii after eyestalk ablation [23]. Though eyestalk ablation induced precocious molting in several species of crustaceans, the same technique failed to induce molting in spiny lobster Panulirus argus [24]. In the same species Travis [25] reported that eyestalk ablation does accelerates precocious molting as well as gonadal activity but not simultaneously, indicating the molting and reproduction in this lobster are antagonistic events.

The X-organ sinus gland complex is located in the eyestalks and is responsible for the synthesis, storage and release of different peptide hormones. Molt-inhibiting hormone (MIH) is one of the important eyestalk peptide hormones and is involved in the regulation of molting.
$\mathrm{MIH}$ regulates the molting process by suppressing the synthesis and release of molting hormone, ecdysone, by Y-organs (molting glands). Freeman and Bartall [26], and Bruce and Chang [27] have demonstrated the presence of molt-inhibiting hormone in the eyestalks of Penaeus pugio and Homarus americanus respectively. Ablation of eyestalk leads to elimination of MIH ultimately the molt induction [23]. The decreased levels of MIH in the hemolymph was observed after eyestalk ablation [28] and at the same time the increased ecdysteroid levels were also observed in the hemolymph $[29,30]$. Decreased titers of hemolymph ecdysteroids during the intermolt, maximum levels during the premolt and low levels just prior to ecdysis was observed in crayfishes Orconectes sanborni [31] and Procambarus clarkii [32] and in the blue crab Callinectes sapidus [33].

In the last decade the level of MIH mRNA expression in the $\mathrm{X}$-organ of the blue crab Callinectes sapidus [34] and the MIH content in the sinus glands of the crayfish Procambarus clarkii [32] and Cherax quadricarinatus [3] were estimated at each stage of molt cycle. Nakatsuji and Sonobe [35] demonstrated the changes in the hemolymph MIH levels during the molt cycle in the American crayfish Procambarus clarkii. They observed the titer of hemolymph MIH at intermolt stage $(6.53 \mathrm{fmol} / \mathrm{ml})$ was about five times higher than that at the early premolt stage $(1.28 \mathrm{fmol} / \mathrm{ml})$. The above studies clearly indicates the role of $\mathrm{MIH}$ in the regulation of molting in crustaceans.

The another eyestalk neuropeptide called mandibular organinhibiting hormone $(\mathrm{MOIH})$ also involved in the regulation of molting in crustaceans. MOIH inhibits the synthesis and secretion of sesquiterpenoid hormone methyl farnesoate (MF) by mandibular organs. MF is known to regulate molting in many crustacean species [36-38].

The possible involvement of mandibular organ in the regulation of molt cycle was demonstrated in several crustaceans. Nagaraju et 
al., [36] observed the size of mandibular organs at different stages of molt cycle in the crab $O$. senex senex and reported an increase in the size of the mandibular organ when the crab enters in to premolt. The morphological changes of the mandibular organ during the molt cycle in the American lobster Homarus americanus was also studied [39]. Hinsch [40] observed the increased synthetic activity of the mandibular organ during induced molt cycle along with the ultra-structural changes in the male spider crab, Libinia emarginata. The increased synthetic activity of the mandibular organ during premolt period may be due to the release of mandibular organ cells from suppression of methyl farnesoate synthesis by MOIH. It is clear that the eyestalk peptide hormones inhibit the synthesis and secretion of MF from mandibular organs and ultimately molting.

In the present study, the surgical extirpation of the eyestalk resulted in shortened molt cycle intervals in the crab $O$. senex senex. This may be due to the reduction of titers of $\mathrm{MIH}$, and/or MOIH from circulation after the removal of eyestalks thereby results in increased levels of MF and ecdysteroids from mandibular organ and Y-organ respectively. The increased levels of MF and ecdysteroids are known to shorten the molt cycle duration.

The natural molt cycle with demarcated molt stages have elucidated in the present study in the crab O. senex senex. The detailed natural molt cycle of crab may show a way in studying induced molt cycle with various molecules/factors like xenoestrogens, various metals, vertebrate type steroids, biotic and abiotic factors etc., including manipulation of crustacean hormones. Eyestalk extirpation induced molting with reduced molt cycle duration but found mortality suggesting the need for search an effective alternative method for induced molt in crustaceans.

\section{Acknowledgement}

We thank the University Grants Commission (UGC), New Delhi for providing the financial support in the form of research grant (F.No. 41-582/2012 (SR)) to Dr P. Ramachandra Reddy, Assistant Professor, Yogi Vemana University, Kadapa, AP, India

\section{References}

1. Katayama H, Nagata K, Ohira T, Yumoto F, Tanokura M, et al. (2003) The solution structure of molt-inhibiting hormone from the kuruma prawn Marsupenaeus japonicus. Jour Biol Chem 278: 9620-9623.

2. Webster SG, Keller R, Dircksen $\mathrm{H}$ (2012) The $\mathrm{CHH}$-superfamily of multifunctional peptide hormones controlling crustacean metabolism, osmoregulation moulting, and reproduction. Gen Comp Endocrinol. 175: 217-233.

3. Reddy PR, Rosen O, Manor R, Chung JS, Zmora N, et al. (2012) A stimulation of molt by RNA interference of the molt-inhibiting hormone in the crayfish Cherax quadricarinatus. Gen Comp Endocrinol 178: 227-236.

4. Aiken DE, Waddy SL (1992) The growth process in crayfish. Rev Aquatic Sc 6: 335-381.

5. Sarda F, Cross ML (1984) Calcium and magnesium metabolism during the molt in Nephrops norvegicus (L). Inv Pseq 48: 377-397.

6. Nakatsuji T, Sonobe $\mathrm{H}$ (2004) Regulation of ecdysteroid secretion from the Y-organ by molt inhibiting hormone in the American crayfish, Procambarus clarkii. Journal of Genetic and Comparative Endocrinology 135: 358-364.

7. Reddy PR, Kiranmayi P, Thanuja KK, Reddy PR (2006) 17 $\alpha$-Hydroxyprogesterone induced gonad growth and vitellogenesis in the freshwater rice field crab Oziotelphusa senex senex. Aquaculture 254: 768-775.

8. Allayie SA, Ravichandran S, Bhat BA (2011) Hormonal regulatory role of eyestalk factors on growth of heart in mud crab Scylla serrata. Saudi J Biol Sci 18: $283-286$

9. Techa S, Sook CJ (2015) Ecdysteroids regulate the levels of Molt inhibiting hormone $(\mathrm{MIH})$ expression in the blue crab. Callinectes sapidus PLoSONE10 4: e0117278.
10. Chen S, Jingwei W, Huner JV, Malone RF (1995) Effects of temperature upon ablation-to-molt interval and mortality of red swamp crawfish (Procambarus clarkii) subjected to bilateral eyestalk ablation. Aquaculture 138: 205-217.

11. Meade M, Watts S (2001) Physiological compensation in unilateral eyestalk ablated crayfish, Cherax quadricarinatus. Journal of Experimental Zoology 289: 184-189.

12. Venkitraman PR, Jayalakshmy KV, Balasubramanian T, Maheswari N, Nair KKC (2004) Effects of eyestalk ablation on molting and growth of penaeid prawn Metapenaeus dobsoni (de Man), Indian. Journal of Experimental Biology 42: $403-412$

13. Majid AH, Nader S, Azadeh A, Ahmad B (2008) Influence of eyestalk ablation and temperature on molting and mortality of narrow-clawed crayfish (Astacus leptodactylus). Turkish Journal of Fisheries and Aquatic Sciences 8: 219-223.

14. Drach P (1939) Mue et cycle d'intermue chezles Crustace's Decapodes. Ann Inst Oceanogr, Monaco. 18: 103-391.

15. Drach $P$ (1944) Etude preliminaire sur le cycle d'intermue et son contionnement hormonal chezLeander serratus (Pennaut). Bull Biol France et Belg 78: 48-62.

16. Kurup NG (1963) Crustacean hormones. J Anim Morph Physiol 10: 113-149.

17. Reddy PS (1991) Neuroendocrine control of metabolism in the freshwater field crab Oziothelphusa senex senex Fabricius. Jour Crust Biol 10: 595-607.

18. Braun M (1875) Ueber die histologischen Vorgänge bei der Häutung von Astacus fluviatilis. Arb Zool Inst Würzburg 2: 121-166.

19. Keller R (1992) Crustacean neuropeptides: structures, functions and comparative aspects. Experientia 48: 439-448.

20. Reddy PS, Ramamurthy R (1999) Recent trends in crustacean endocrinology. PINSA 65: 15-32.

21. Chang ES (2001) Crustacean hyperglycemic hormone family: Old paradigms and new perspectives. Amer Zool 41: 380-388.

22. Rotllant G, Takac P, Liu L, Scott GL, Laufer H (2000) Role of ecdysteroids and methyl farnesoate in morphogenesis and terminal moult in polymorphic males of spider crab Libinia emarginata. Aquaculture 190: 103-118.

23. Okumura T, Aida K (2001) Effects of bilateral eyestalk ablation on molting and ovarian development in the giant freshwater prawn Macrobrachium rosenbergii. Fish Sci 67: 1125-1135.

24. Quackenbush LS, Herrnkind WF (1981) Regulation of molt and gonadal development in the spiny lobster, Panulirus argus (Crustacea; Palinuridae); Effect of eyestalk ablation. Comp Biochem Physiol 69: 523-527.

25. Travis DF (1954) The molting cycle of the spiny lobster, Panulirus argus Latreille. I. Molting and growth in laboratory maintained individuals. Biol Bull 107: 433-450.

26. Freeman JA, Bartell CK (1975) Characterization of the molt cycle and it hormonal control in Palaemonetes (Penaeus) pugio (Decapoda, Caridea). Gen Comp Endocrinol 25: 517-528.

27. Bruce MJ, Chang ES (1984) Demonstration of molt-inhibiting hormone from the sinus gland of the lobster Homarus americanus. Comp Biochem Physio 79: $421-424$

28. Mattson MP (1986) New insights into neuroendocrine regulation of the crustacean molt cycle. Zoological Science 3: 733-744.

29. Chang ES (1985) Cellular juvenile hormone binding proteins. Meth Enzymol 111: 494-509.

30. Karplus I, Hulata G (1995) Social control of growth in Macrobrachium rosenbergii. V. The effect of unilateral eyestalk ablation on jumpers and laggards. Aquaculture 138:181-190.

31. Stevenson GR, Amstrong PW, Chang ES, O'Connor JD (1979) Ecdysone titers during the molt cycle of the crayfish Orconectes sanborni. Gen Comp Endocrinol 39: 20-25

32. Nakatsuji T, Keino H, Tamura K, Yoshimura S, Kawakami T, et al. (2000) Changes in the amounts of the molt-inhibiting hormone in sinus glands during the molt cycle of the American crayfish Procambarus clarkia. Zool Sci 17: 1129 1136

33. Soumoff C, Skinner DM (1983) Ecdysteroid titers during the molt cycle of the blue crab resemble those of other crustacea. Biol Bull 165: 321-329. 
Citation: Hosamani N, Pamuru RR, Pamanji SR (2016) Natural and Induced (EyestalkAblation) Molt Cycle in Freshwater Rice Field Crab Oziothelphusa Senex Senex. J Aquac Res Development. 7: 424. doi:10.4172/2155-9546.1000424

34. Lee KJ, Watson RD, Roer RD (1998) Molt-inhibiting hormone mRNA levels and ecdysteroid titer during a molt cycle of the blue crab, Callinectes sapidus. Biochem Biophys Res Commun 249: 624-627.

35. Nakatsuji T, Sonobe H (2003) Measurement of molt-inhibiting hormone titer in hemolymph of the American crayfish, Procambarus clarkii by time resolved fluoroimmunoassay. Zool Sci 20: 999-1001.

36. Nagaraju GPC, Reddy PR, Reddy PS (2004) Mandibular organ: it's relation to body weight, sex, molt and reproduction in the crab, Oziothelphusa senex senex Fabricius. Aquaculture 232: 603-612.

37. Nagaraju GPC, Reddy PR, Reddy PS (2006) In vitro methyl farnesoate secretion by mandibular organs isolated from different molt and reproductive stages of the crab Oziothelphusa senex senex. Fish Sci 72: 410-414.

38. Reddy PR, Nagaraju GPC, Reddy PS (2004) Involvement of methyl farnesoate in the regulation of molting and reproduction in the freshwater crab Oziothelphusa senex senex. J Crust Biol 24: 511-515.

39. Byard EH (1975) The female specific protein and reproduction in the lobster Homarus americanus. Ph.D. thesis, University of Western Ontario, London, Ontario.

40. Hinsch GW (1977) Fine structural changes in the mandibular gland of the male spider crab, Libinia emarginata (L) following eyestalk ablation. Jour Morph 154 307-316. 